Article

\title{
Two New Terpenes Isolated from Dictyostelium Cellular Slime Molds
}

\author{
Hitomi Sasaki ${ }^{1}$, Yuzuru Kubohara ${ }^{2} \mathbb{D}$, Hirotaka Ishigaki ${ }^{3}$, Katsunori Takahashi ${ }^{3}$, Hiromi Eguchi ${ }^{1}$, \\ Akihiro Sugawara ${ }^{1} \mathbb{D}$, Yoshiteru Oshima ${ }^{1}$ and Haruhisa Kikuchi ${ }^{1, *(\mathbb{D})}$ \\ 1 Graduate School of Pharmaceutical Sciences, Tohoku University, 6-3, Aza-Aoba, Aramaki, Aoba-ku, \\ Sendai 980-8578, Japan; sasaki.hitomi@toaeiyo.co.jp (H.S.); hiromi.e@me.com (H.E.); \\ sugawara@mail.pharm.tohoku.ac.jp (A.S.); oshima@mail.pharm.tohoku.ac.jp (Y.O.) \\ 2 Graduate School of Health and Sports Science, Juntendo University, 1-1 Hiraga-gakuendai, Inzai, \\ Chiba 270-1695, Japan; ykuboha@juntendo.ac.jp \\ 3 Department of Medical Technology, Faculty of Health Science, Gunma Paz University, Takasaki 370-0006, Japan; \\ ishigaki@paz.ac.jp (H.I.); k-takahashi@paz.ac.jp (K.T.) \\ * Correspondence: hal@mail.pharm.tohoku.ac.jp; Tel.: +81-22-795-6824
}

Academic Editor: Rosa M. Durán-Patrón

check for Received: 28 May 2020; Accepted: 18 June 2020; Published: 23 June 2020

\begin{abstract}
We report a protoilludane-type sesquiterpene, mucoroidiol, and a geranylated bicyclogermacranol, firmibasiol, isolated from Dictyostelium cellular slime molds. The methanol extracts of the fruiting bodies of cellular slime molds were separated by chromatographic methods to give these compounds. Their structures have been established by several spectral means. Mucoroidiol and firmibasiol are the first examples of more modified and oxidized terpenoids isolated from cellular slime molds. Mucoroidiol showed moderate osteoclast-differentiation inhibitory activity despite demonstrating very weak cell-proliferation inhibitory activity. Therefore, cellular slime molds produce considerably diverse secondary metabolites, and they are promising sources of new natural product chemistry.
\end{abstract}

Keywords: cellular slime molds; dictyostelid; natural products; terpenoids

\section{Introduction}

Natural products, particularly those derived from microorganisms such as fungi and bacteria, have long played an essential role in the development of novel drugs [1] However, pharmaceutical research into natural products has recently declined because of factors such as increased difficulty in identifying new compounds with skeletally novel structures $[2,3]$. Thus, novel natural resources for natural products are required.

Cellular slime molds are a group of soil microorganisms that belong to the eukaryotic kingdom Amoebozoa, which is taxonomically distinct from fungi [4,5] The cellular slime mold Dictyostelium discoideum has been used as a model organism for studying eukaryotic cell functions because of its simple developmental pattern and ease of handling [6-9] Vegetative cells of D. discoideum grow as single ameba by eating bacteria. When these cells are starved, they initiate a developmental program of morphogenesis, forming a slug-shaped multicellular aggregate. This aggregate differentiates into two cell types, prespore and prestalk cells, which are precursors to spores and stalk cells, respectively. At the end of its development, the aggregate forms a fruiting body consisting of spores and a multicellular stalk [10].

We have focused on the utility of cellular slime molds as a source of natural compound [11] and have isolated $\alpha$-pyronoids [12-14] amino sugar derivatives [15], and aromatics [16-19] with unique structures 
and various biological activities. For example, brefelamide [16] and its derivatives exhibit inhibitory effects on osteopontin expression [20,21] and immune checkpoint PD-L1 expression [22]. The above results indicate that cellular slime molds are an important source of lead compounds for drug discovery.

In this paper, we report upon the isolation and structural elucidation of mucoroidiol (1), a protoilludane-type sesquiterpene from $D$. mucoroides, and firmibasiol (2), a geranylated sesquiterpene from D. firmibasis (Figure 1).

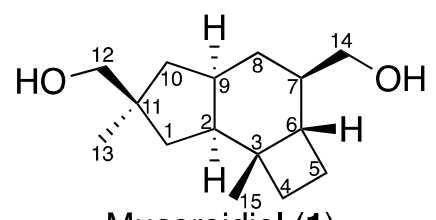

Mucoroidiol (1)

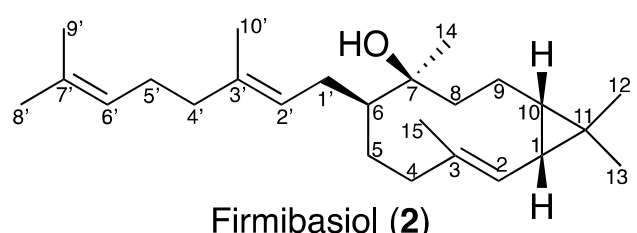

Firmibasiol (2)

Figure 1. Structures of mucoroidiol (1) and firmibasiol (2).

\section{Results}

\subsection{Isolation and Structural Elucidation of Mucoroidiol}

Multicellular fruiting bodies (80 g dry weight) of D. mucoroides Dm7 were cultured on agar plates in the presence of $0.5 \mathrm{mM} \mathrm{ZnCl}_{2}$ [23]. They were extracted three times with methanol at room temperature to yield an extract $(10 \mathrm{~g})$, which was then partitioned between ethyl acetate and water. The fraction soluble in ethyl acetate $(2.8 \mathrm{~g})$ was separated by silica-gel column chromatography and gel permeation column chromatography to afford mucoroidiol (1) $(1.3 \mathrm{mg})$.

HRFAB-MS $\left(\mathrm{m} / \mathrm{z} 239.2011[\mathrm{M}+\mathrm{H}]^{+}\right)$indicated the molecular formula of $\mathbf{1}$ as $\mathrm{C}_{15} \mathrm{H}_{26} \mathrm{O}_{2}$. The NMR spectra of $\mathbf{1}$ are shown in Supplementary Materials (Pages S2 S4). The ${ }^{13} \mathrm{C}$ NMR spectrum of $\mathbf{1}$ showed the presence of two quaternary, four methine, seven methylene, and two methyl carbons (Table 1 ). The ${ }^{1} \mathrm{H}-{ }^{1} \mathrm{H}$ COSY correlations revealed the connectivity of C-1-C-2-C-9(-C-10)-C-8-C-7(-C-14)-C-6-C-5-C-4. The HMBC correlations of $\mathrm{H}_{3}-15$ to $\mathrm{C}-2, \mathrm{C}-3, \mathrm{C}-4$ and $\mathrm{C}-6 ; \mathrm{H}_{2}-12$ to $\mathrm{C}-1, \mathrm{C}-10$ and $\mathrm{C}-11$; and $\mathrm{H}_{3}-13$ to $\mathrm{C}-1, \mathrm{C}-10$ and $\mathrm{C}-11$ confirmed the protoilludane skeleton of $\mathbf{1}$ (Figure 2A). The cross-peaks of $\mathrm{H}-2$ to $\mathrm{H}-4 \alpha, \mathrm{H}-9$, and $\mathrm{H}_{3}-13$, as well as those of $\mathrm{H}-9$ to $\mathrm{H}-4 \alpha$ and $\mathrm{H}-7$, revealed that these protons faced the $\alpha$-plane, and that the relative configurations at C-2, C-7, C-9 and C-11 are determined as $S^{*}, R^{*}, R^{*}$ and $R^{*}$, respectively. Conversely, correlations from $\mathrm{H}_{3}-15$ to $\mathrm{H}-1 \beta$ and $\mathrm{H}-5 \beta$ in the NOESY spectrum revealed that these protons faced the $\beta$-plane, and that the relative configurations at C- 3 and C- 6 are determined as $R^{*}$ and $S^{*}$, respectively (Figure $2 \mathrm{~B}$ ). The yield of $\mathbf{1}$ was so small that its absolute configuration could not be determined by chemical conversion. On the other hand, it was reported that the incubation of DdTPS6 (a terpene cyclase of $D$. discoideum) with farnesyl diphosphate afforded $(2 S, 3 R, 6 S, 7 R, 9 S)$-protoillud-7-ene (3) via carbocation intermediate A (Scheme 1) [24]. Some terpene cyclases of D. mucoroides would be evolutionary common with those of $D$. discoideum, indicating that the absolute configurations of $\mathbf{1}$ should be common with 3 . Thus, the absolute configurations of 1 are assumed to be $2 S, 3 R, 6 S, 7 R, 9 R$, and $11 R$. 
Table 1. NMR spectral data of mucoroidiol (1) ${ }^{\mathrm{a}}$.

\begin{tabular}{|c|c|c|c|}
\hline & ${ }^{13} \mathrm{C}$ & (DEPT) & ${ }^{1} \mathbf{H}$ \\
\hline 1 & 37.0 & $\mathrm{CH}_{2}$ & $\begin{array}{c}1.23(1 \mathrm{H}, \mathrm{dd}, J=12.5,6.5 \mathrm{~Hz}) \\
1.32-1.37(1 \mathrm{H}, \mathrm{m})\end{array}$ \\
\hline 2 & 45.6 & $\mathrm{CH}$ & $1.84(1 \mathrm{H}, \mathrm{dt}, J=12.9,6.5 \mathrm{~Hz})$ \\
\hline 3 & 39.0 & $\mathrm{C}$ & \\
\hline 4 & 31.7 & $\mathrm{CH}_{2}$ & $\begin{array}{c}1.42-1.47(1 \mathrm{H}, \mathrm{m}) \\
2.03(1 \mathrm{H}, \mathrm{q}, J=9.4 \mathrm{~Hz})\end{array}$ \\
\hline 5 & 24.4 & $\mathrm{CH}_{2}$ & $\begin{array}{l}1.33-1.37(1 \mathrm{H}, \mathrm{m}) \\
2.14-2.21(1 \mathrm{H}, \mathrm{m})\end{array}$ \\
\hline 6 & 40.2 & $\mathrm{CH}$ & $1.33-1.39(1 \mathrm{H}, \mathrm{m})$ \\
\hline 7 & 44.7 & $\mathrm{CH}$ & $1.60-1.63(1 \mathrm{H}, \mathrm{m})$ \\
\hline 8 & 30.3 & $\mathrm{CH}_{2}$ & $\begin{array}{c}0.78(1 \mathrm{H}, \mathrm{q}, J=12.9 \mathrm{~Hz}) \\
1.35-1.41(1 \mathrm{H}, \mathrm{m})\end{array}$ \\
\hline 9 & 38.4 & $\mathrm{CH}$ & $2.10-2.16(1 \mathrm{H}, \mathrm{m})$ \\
\hline 10 & 42.8 & $\mathrm{CH}_{2}$ & $\begin{array}{c}1.30-1.35(1 \mathrm{H}, \mathrm{m}) \\
1.59(1 \mathrm{H}, \mathrm{dd}, J=13.5,7.8 \mathrm{~Hz})\end{array}$ \\
\hline 11 & 41.7 & $\mathrm{C}$ & \\
\hline 12 & 73.0 & $\mathrm{CH}_{2}$ & $\begin{array}{l}3.34(1 \mathrm{H}, \mathrm{d}, J=10.6 \mathrm{~Hz}) \\
3.37(1 \mathrm{H}, \mathrm{d}, J=10.6 \mathrm{~Hz})\end{array}$ \\
\hline 13 & 26.5 & $\mathrm{CH}_{3}$ & $0.99(3 \mathrm{H}, \mathrm{s})$ \\
\hline 14 & 67.2 & $\mathrm{CH}_{2}$ & $\begin{array}{c}3.32-3.37(1 \mathrm{H}, \mathrm{m}) \\
3.51(1 \mathrm{H}, \mathrm{dd}, J=10.5,4.8 \mathrm{~Hz})\end{array}$ \\
\hline 15 & 26.3 & $\mathrm{CH}_{3}$ & $1.11(3 \mathrm{H}, \mathrm{s})$ \\
\hline
\end{tabular}
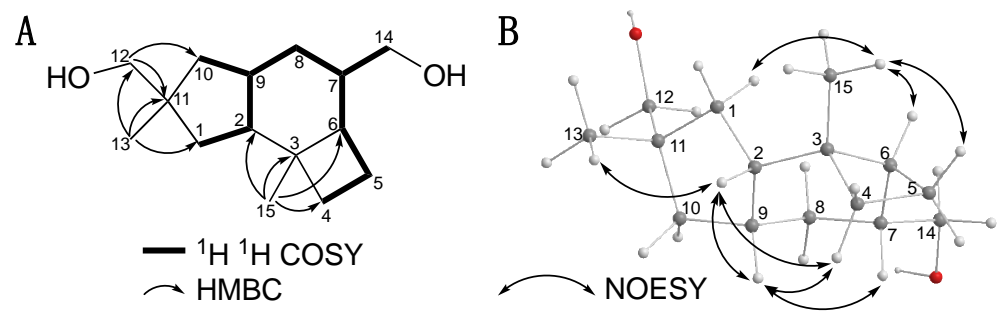

Figure 2. The structural elucidation of mucoroidiol (1). (A). Planar structure of $\mathbf{1}$ and representative correlations of ${ }^{1} \mathrm{H}_{-}{ }^{1} \mathrm{H}$ COSY and HMBC spectra. (B). Relative structure of $\mathbf{1}$ and representative correlations of NOESY spectrum.

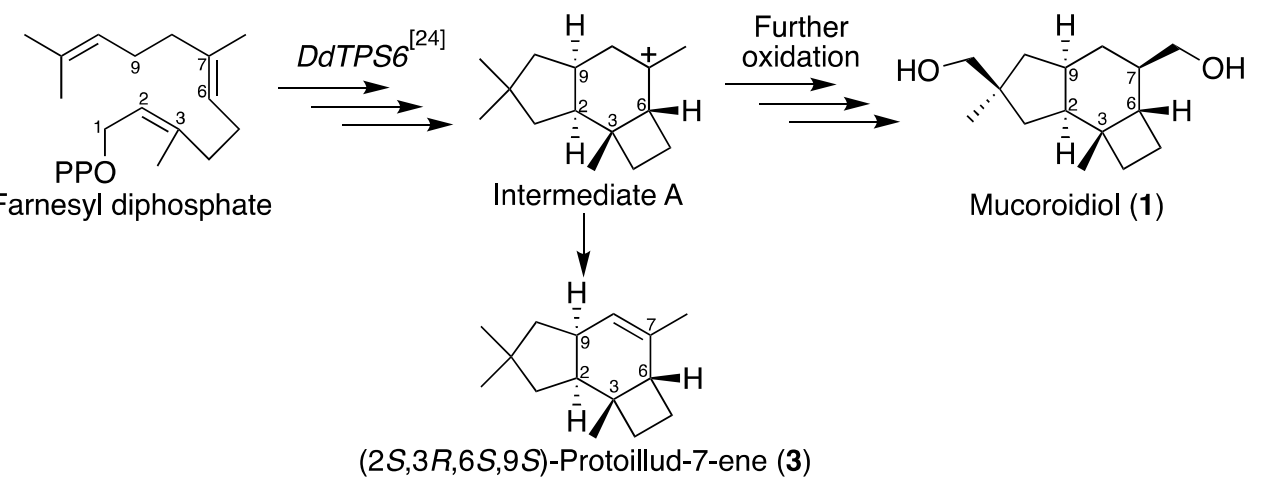

Scheme 1. The plausible biosynthetic pathway of mucoroidiol (1). 


\subsection{Isolation and Structural Elucidation of Firmibasiol}

Multicellular fruiting bodies (48 g dry weight) of the cellular slime mold (D. firmibasis 91HO-33) were cultured on plates and extracted three times with methanol at room temperature to yield an extract (11 g), which was partitioned between ethyl acetate and water. The fraction soluble in ethyl acetate $(2.3 \mathrm{~g})$ was separated by repeated column chromatography over silica gel and octadecyl silica gel to yield firmibasiol (2) (1.8 mg).

HREI-MS $\left(\mathrm{m} / \mathrm{z} 358.3258[\mathrm{M}]^{+}\right)$indicated the molecular formula of 2 as $\mathrm{C}_{25} \mathrm{H}_{42} \mathrm{O}$. The NMR spectra of 2 are shown in Supplementary Materials (Pages S5 S7). The ${ }^{13} \mathrm{C}$ NMR spectrum of 2 showed the presence of six olefinic, two quaternary, three methine, seven methylene, and seven methyl carbons (Table 2). The HMBC correlations of $\mathrm{H}_{3}-15$ to $\mathrm{C}-2, \mathrm{C}-3$ and $\mathrm{C}-4 ; \mathrm{H}_{3}-14$ to $\mathrm{C}-6, \mathrm{C}-7$ and $\mathrm{C}-8 ; \mathrm{H}_{3}-12$ to $\mathrm{C}-1, \mathrm{C}-10$ and $\mathrm{C}-11$; and $\mathrm{H}_{3}-13$ to $\mathrm{C}-1, \mathrm{C}-10$ and $\mathrm{C}-11$ connect the partial structures confirmed by the ${ }^{1} \mathrm{H}-{ }^{1} \mathrm{H}$ COSY spectrum established the bicyclogermacrane moiety of 2 (Figure $3 \mathrm{~A}$ ). In addition, the HMBC correlations of $\mathrm{H}_{3}-10^{\prime}$ to $\mathrm{C}-2^{\prime}, \mathrm{C}-3^{\prime}$ and $\mathrm{C}-4^{\prime}$; and $\mathrm{H}_{3}-9^{\prime}$ to $\mathrm{C}-6^{\prime}, \mathrm{C}-7^{\prime}$ and $\mathrm{C}-8^{\prime}$ revealed the 1-geranylated bicyclogermacrane structure of 2 . The cross-peaks of $\mathrm{H}_{3}-12-\mathrm{H}-10, \mathrm{H}_{3}-12-\mathrm{H}-1, \mathrm{H}-1-\mathrm{H}_{3}-15$, and $\mathrm{H}_{3}-15-\mathrm{H}-5 \beta$ in the NOESY spectrum revealed that these protons faced the $\beta$-plane (Figure 3B). Since H-1, H-10, and $\mathrm{H}_{3}-12$ direct to the same side, the relative configurations at $\mathrm{C}-1$ and $\mathrm{C}-10$ are determined as $R^{*}$ and $S^{*}$, respectively. Conversely, the cross-peaks of $\mathrm{H}_{3}-13-\mathrm{H}-2, \mathrm{H}-2-\mathrm{H}-6$, and $\mathrm{H}-2-\mathrm{H}-9 \alpha$ indicated that these protons faced the $\alpha$-plane, determining that the olefin between $C-2$ and $C-3$ has an $E$-configuration, and the relative configuration at C-6 is $S^{*}$. In addition, the cross-peaks of $\mathrm{H}-9 \beta-\mathrm{H}_{3}-14$ and $\mathrm{H}_{3}-14-\mathrm{H}_{2}-1^{\prime}$ indicated that these protons faced the same direction (Figure $3 \mathrm{C}$ ), indicating that the relative configuration at $\mathrm{C}-7$ is $S^{*}$. In addition, the NOESY cross-peak between $\mathrm{H}^{-1}{ }^{\prime}$ and $\mathrm{H}_{3}-10^{\prime}$ revealed that the olefin between $\mathrm{C}-2^{\prime}$ and $C-3^{\prime}$ also has an E-configuration. The yield of $\mathbf{2}$ was very small such that its absolute configuration could not be determined by chemical conversion. On the other hand, it was reported that the incubation of DdTPS8 (a terpene cyclase of D. discoideum) with farnesyl diphosphate afforded (S)-hedycaryol (4) via carbocation intermediate B (Scheme 2) [25]. Firmibasiol (2) is presumed to be biosynthesized from intermediate $\mathrm{B}$, which would be converted into $(1 R, 10 S)$-bicyclogermacrene (5). Subsequently, the C-6-C-7 olefin attacks geranyl diphosphate, and water addition to the carbocation intermediate $\mathrm{C}$ at $\mathrm{C}-7$ produces 2. Through this plausible biosynthetic route, the absolute configurations of $C-10$ in 2 should be retained from carbocation intermediate B. Therefore, the absolute configurations of 2 are assumed to be $1 R, 6 S, 7 S$, and 10S. Although firmibasiol (2) contains five isoprene units $\left(C_{25}\right)$, it is not a sesterterpene, but rather a geranylated sesquiterpene. Prenylated terpenoids such as $\mathbf{2}$ are very rare types of natural compounds; only one compound has been reported so far [26].

\subsection{Biological Activity of Compounds 1 and 2}

Mucoroidiol (1) and firmibasiol (2) were screened to investigate several types of biological activities. Osteoclasts are multinucleated cells that resorb bone tissue. They are formed by the fusion of mononuclear monocyte/macrophage lineage precursor cells. Excessive bone resorption often results in osteoporosis and rheumatoid arthritis [27]. Firmibasiol (2) showed moderate receptor activator of NF- $\mathrm{kB}$ ligand (RANKL)-induced osteoclast-differentiation inhibitory activity $\left(\mathrm{IC}_{50} 28 \mu \mathrm{M}\right)$ by measurement of activity of tartrate-resistant acid phosphatase (TRAP) [28] (Figure 4), while mucoroidiol (1) did not show remarkable inhibitory activity. On the other hand, mucoroidiol (1) and firmibasiol (2) exhibited weak anti-proliferative activity against HeLa cells $\left(\mathrm{IC}_{50}>40 \mu \mathrm{M}\right)$, but did not show apparent anti-bacterial activities both in Gram-positive (Staphylococcus aureus) and Gram-negative (Escherichia coli) bacteria (Table 3). 
Table 2. NMR spectral data of firmibasiol (2) ${ }^{\mathrm{a}}$.

\begin{tabular}{|c|c|c|c|}
\hline & ${ }^{13} \mathrm{C}$ & (DEPT) & ${ }^{1} \mathbf{H}$ \\
\hline 1 & 25.1 & $\mathrm{CH}$ & $1.28(1 \mathrm{H}, \mathrm{t}, J=9.0 \mathrm{~Hz})$ \\
\hline 2 & 121.0 & $\mathrm{CH}$ & $4.88(1 \mathrm{H}, \mathrm{d}, J=9.0 \mathrm{~Hz})$ \\
\hline 3 & 137.2 & $\mathrm{C}$ & \\
\hline 4 & 40.5 & $\mathrm{CH}_{2}$ & $\begin{array}{c}1.80(1 \mathrm{H}, \mathrm{t}, J=12.0 \mathrm{~Hz}) \\
2.07-2.11(1 \mathrm{H}, \mathrm{m})\end{array}$ \\
\hline 5 & 26.7 & $\mathrm{CH}_{2}$ & $\begin{array}{l}1.18-1.25(1 \mathrm{H}, \mathrm{m}) \\
1.44-1.51(1 \mathrm{H}, \mathrm{m})\end{array}$ \\
\hline 6 & 42.3 & $\mathrm{CH}$ & $1.41-1.45(1 \mathrm{H}, \mathrm{m})$ \\
\hline 7 & 76.0 & $\mathrm{C}$ & \\
\hline 8 & 38.3 & $\mathrm{CH}_{2}$ & $1.18-1.27(2 \mathrm{H}, \mathrm{m})$ \\
\hline 9 & 21.3 & $\mathrm{CH}_{2}$ & $\begin{array}{c}0.58(1 \mathrm{H}, \mathrm{q}, J=12.0 \mathrm{~Hz}) \\
1.50-1.54(1 \mathrm{H}, \mathrm{m})\end{array}$ \\
\hline 10 & 27.8 & $\mathrm{CH}$ & $0.66(1 \mathrm{H}, \mathrm{ddd}, J=12.0,9.0,3.6 \mathrm{~Hz})$ \\
\hline 11 & 20.1 & $\mathrm{C}$ & \\
\hline 12 & 28.8 & $\mathrm{CH}_{3}$ & $1.04(3 \mathrm{H}, \mathrm{s})$ \\
\hline 13 & 15.1 & $\mathrm{CH}_{3}$ & $1.11(3 \mathrm{H}, \mathrm{s})$ \\
\hline 14 & 25.8 & $\mathrm{CH}_{3}$ & $1.07(3 \mathrm{H}, \mathrm{s})$ \\
\hline 15 & 17.3 & $\mathrm{CH}_{3}$ & $1.73(3 \mathrm{H}, \mathrm{s})$ \\
\hline $1^{\prime}$ & 30.2 & $\mathrm{CH}_{2}$ & $2.08-2.14(2 \mathrm{H}, \mathrm{m})$ \\
\hline $2^{\prime}$ & 123.1 & $\mathrm{CH}$ & $5.27(1 \mathrm{H}, \mathrm{t}, J=7.2 \mathrm{~Hz})$ \\
\hline $3^{\prime}$ & 136.2 & C & \\
\hline $4^{\prime}$ & 40.0 & $\mathrm{CH}_{2}$ & $2.03(2 \mathrm{H}, \mathrm{t}, J=7.2 \mathrm{~Hz})$ \\
\hline $5^{\prime}$ & 26.8 & $\mathrm{CH}_{2}$ & $2.05-2.10(2 \mathrm{H}, \mathrm{m})$ \\
\hline $6^{\prime}$ & 124.3 & $\mathrm{CH}$ & $5.01(1 \mathrm{H}, \mathrm{tq}, J=7.2,1.2 \mathrm{~Hz})$ \\
\hline $7^{\prime}$ & 131.5 & $\mathrm{C}$ & \\
\hline $8^{\prime}$ & 25.7 & $\mathrm{CH}_{3}$ & $1.68(3 \mathrm{H}, \mathrm{d}, J=7.2,1.2 \mathrm{~Hz})$ \\
\hline $9^{\prime}$ & 17.7 & $\mathrm{CH}_{3}$ & $1.60(3 \mathrm{H}, \mathrm{s})$ \\
\hline $10^{\prime}$ & 16.3 & $\mathrm{CH}_{3}$ & $1.63(3 \mathrm{H}, \mathrm{s})$ \\
\hline
\end{tabular}
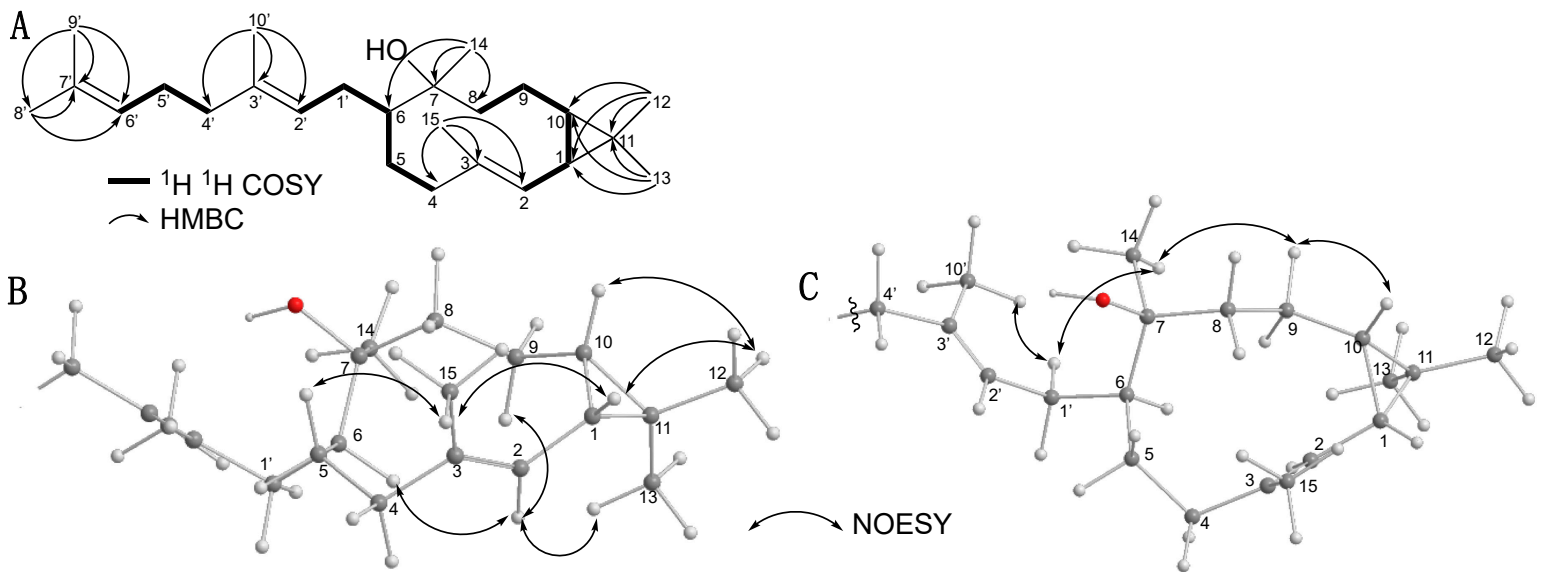

Figure 3. The structural elucidation of firmibasiol (2) (A). Planar structure of 2 and representative correlations of ${ }^{1} \mathrm{H}-{ }^{1} \mathrm{H}$ COSY and HMBC spectra. (B,C). Relative structure (side view (B) and top view (C)) of 2 and representative correlations of the NOESY spectrum. 


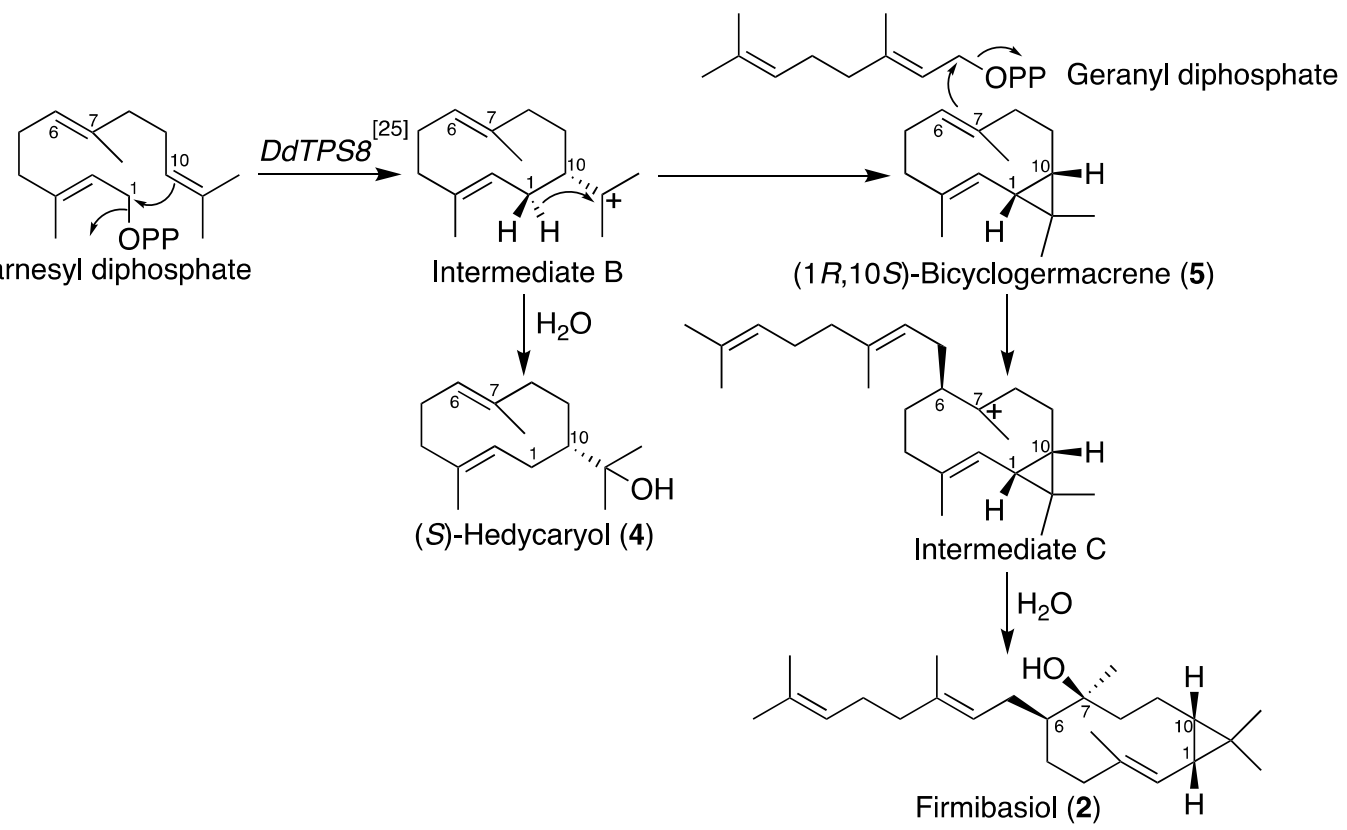

Scheme 2. The plausible biosynthetic pathway of firmibasiol (2).

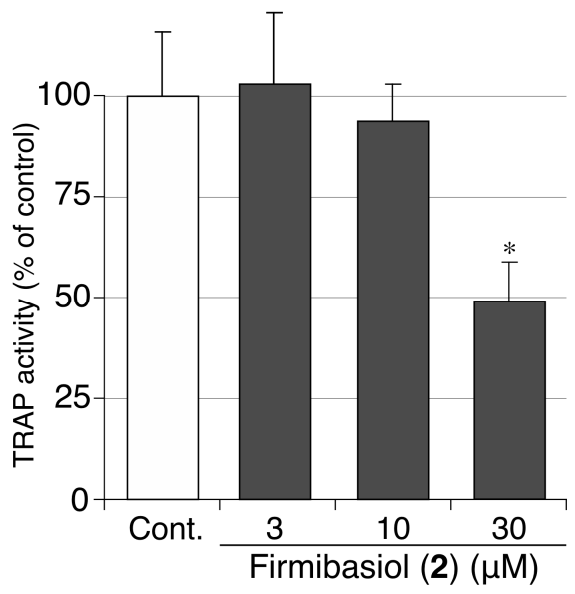

Figure 4. Osteoclastogenesis-suppressive activity of 2.

Table 3. Antitumor and anti-bacterial activities of $\mathbf{1}$ and $\mathbf{2}^{\mathrm{a}}$.

\begin{tabular}{ccccc}
\hline & IC $_{\mathbf{5 0}}(\boldsymbol{\mu} \mathbf{M}) \mathbf{v s .}$ & MIC $(\boldsymbol{\mu M}) \mathbf{v s .}$ \\
\hline & HeLa & S. aureus (MSSA) & S. aureus (MRSA) & E. coli \\
\hline Mucoroidiol (1) & $>40$ & $>100$ & $>100$ & $>100$ \\
Firmibasiol (2) & $>40$ & $>100$ & $>100$ & $>100$ \\
\hline
\end{tabular}

${ }^{a}$ Half maximal (50\%) inhibitory concentration $\left(\mathrm{IC}_{50}\right)$ (versus HeLa cells) and minimum inhibitory concentration (MIC) (versus S. aureus and E. coli) of $\mathbf{1}$ and $\mathbf{2}$ were assessed as described in the Section 4.

The data are expressed as percentages in relation to the mean value of the control cells. The bars indicate the standard deviation of the three wells. The statistical significance of the differences was determined by Welch's $t$-test. ${ }^{*} p<0.05$ vs. control. 


\section{Discussion}

Recently, a phylogenetic analysis revealed that terpene cyclase genes exist in several species of cellular slime molds [29]. D. discoideum emits volatiles containing several types of terpenoid hydrocarbons. These hydrocarbons were produced by the incubation of the recombinant terpene cyclase with farnesyl or geranylgeranyl diphosphate $[24,25,30]$. However, unlike when only terpene cyclase acted, the multicellular fruiting bodies of a cellular slime mold should synthesize several types of modified terpenes converted by various biosynthetic enzymes in vivo. Mucoroidiol (1) is the first example of a terpene diol obtained from cellular slime molds. Firmibasiol (2) is a type of prenylated terpenoid, which is a very rare type of natural compound. Because the isolated amounts of compounds $\mathbf{1}$ and $\mathbf{2}$ were very small, their absolute configuration could not be determined. Instead, they are assumed by biosynthetic similarity with terpenes obtained by terpene cyclases of $D$. discoideum. The determination of their absolute configuration should be made by de novo synthetic studies in the future. On the other hand, firmibasiol (2) showed moderate osteoclast-differentiation inhibitory activity, and can be used as a seed compound for anti-osteoporosis drugs. Therefore, these cellular slime molds are promising sources of new natural product chemistry.

\section{Materials and Methods}

\subsection{General Methods}

Analytical TLC was performed on silica gel $60 \mathrm{~F}_{254}$ (Merck). Silica gel column chromatography was carried out on silica gel 60 (70-230 mesh, Merck). Octadecyl silica gel column chromatography was carried out on Cosmosil 140C 18 -OPN (NACALAI TESQUE, Inc., Kyoto Japan). NMR spectra were recorded on JEOL ECA-600. Chemical shifts for ${ }^{1} \mathrm{H}$ and ${ }^{13} \mathrm{C}$ NMR are given in parts per million $(\delta)$ relative to tetramethylsilane $(\delta \mathrm{H} 0.00)$ and residual solvent signals $(\delta \mathrm{C} 77.0)$ as internal standards. Mass spectra were measured on JEOL JMS-700 and JMS-DX303.

\subsection{Organism and Culture Conditions}

Dictyostelium mucoroides Dm7 was provided by NBRP Nenkin (https://nenkin.nbrp.jp/). Its spores were cultured at $22{ }^{\circ} \mathrm{C}$ with Klebsiella aerogenes on A-medium consisting of $0.5 \%$ glucose, $0.5 \%$ polypeptone, $0.05 \%$ yeast extract, $0.225 \% \mathrm{KH} 2 \mathrm{PO} 4,0.137 \% \mathrm{Na} 2 \mathrm{HPO} 4 \times 12 \mathrm{H} 2 \mathrm{O}, 0.05 \% \mathrm{MgSO} 4 \times 7 \mathrm{H} 2 \mathrm{O}$, and $1.5 \%$ agar. Dictyostelium firmibasis $91 \mathrm{HO}-33$ was kindly supplied by Dr. Hiromitsu Hagiwara, National Science Museum, Tokyo, Japan, and has been deposited into NBRP Nenkin. Its spores were cultured at $22{ }^{\circ} \mathrm{C}$ with Escherichia coli on A-medium. When fruiting bodies had formed after four days, they were harvested for extraction.

\subsection{Isolation of Mucoroidiol (1)}

The fruiting bodies (dry weight $80 \mathrm{~g}$ ) of D. mucoroides Dm7 were collected after cultured in A-medium with $0.5 \mathrm{mM}$ Zinc (II) chloride. They were extracted three times with methanol at room temperature to give an extract $(10 \mathrm{~g})$, which was then partitioned between ethyl acetate and water to yield ethyl acetate solubles $(2.8 \mathrm{~g})$. The ethyl acetate solubles were chromatographed over silica gel, and the column was eluted with hexane-ethyl acetate mixtures with increasing polarity to afford hexane-ethyl acetate (1:3) eluent (fraction A, $67 \mathrm{mg}$ ). Fraction A was further separated by octadecyl silica gel column using water-acetonitrile solvent system to give water-acetonitrile (1:1) elutant (fraction B, $28 \mathrm{mg}$ ). Fraction B was subjected to recycle preparative HPLC (column, GPC-T-2000 ( $\$ 20 \mathrm{~mm} \times 600 \mathrm{~mm}$, YMC Co., Ltd.); solvent, ethyl acetate) to give mucoroidiol (1) (1.3 mg). Data for 1: colorless amorphous solid; $[\alpha]_{\mathrm{D}}{ }^{24}-53.4$ (c 0.13 , chloroform); ${ }^{1} \mathrm{H}$ NMR and ${ }^{13} \mathrm{C}$ NMR spectroscopic data are shown in Table 1; HRFABMS $\mathrm{m} / \mathrm{z} 239.2011$ $[\mathrm{M}+\mathrm{H}]^{+}\left(239.2010\right.$ calculated for $\left.\mathrm{C}_{15} \mathrm{H}_{27} \mathrm{O}_{2}\right)$. 


\subsection{Isolation of Firmibasiol (2)}

The fruiting bodies (dry weight $48 \mathrm{~g}$ ) of $D$. firmibasis $91 \mathrm{HO}-33$ were collected after cultured in A-medium. They were extracted three times with methanol at room temperature to give an extract (11 g), which was then partitioned with ethyl acetate and water to yield ethyl acetate solubles (2.3 g). The ethyl acetate solubles were chromatographed over silica gel and the column was eluted with hexane-ethyl acetate mixtures of increasing polarity to afford hexane-EtOAc (17:3) eluent (fraction C, $356 \mathrm{mg}$ ). Fraction C was separated by ODS column using water-acetonitrile solvent system to give water-acetonitrile (1:4) elutant (fraction D, $20 \mathrm{mg}$ ). Fraction $\mathrm{D}$ was further separated by silica gel column using chloroform to give firmibasiol (2) (1.8 mg). Data for 2: colorless amorphous solid; $[\alpha]_{D}{ }^{26}-30.9$ (c 0.16 , chloroform); ${ }^{1} \mathrm{H}$ NMR and ${ }^{13} \mathrm{C}$ NMR spectroscopic data are shown in Table 2; HREIMS m/z 358.3258 [M] ${ }^{+}$(358.3236 calculated for $\left.\mathrm{C}_{25} \mathrm{H}_{42} \mathrm{O}\right)$.

\subsection{Cell Proliferation Assay}

Human cervical cancer HeLa cells were grown and maintained at $37{ }^{\circ} \mathrm{C}\left(5 \% \mathrm{CO}_{2}\right.$ in air) in Dulbecco's modified Eagle's medium (DMEM) (Catalog No. D5796, Sigma-Aldrich) supplemented with 10\% (v/v) fetal bovine serum (FBS). For cell proliferation assay, HeLa cells were incubated for 3 days in 12 well plates $\left(5 \times 10^{3}\right.$ cells/well), with each well containing $1 \mathrm{~mL}$ of DMEM $(10 \% \mathrm{FBS})$ and the additives in duplicate; the additives were $0.2 \%(v / v)$ dimethyl sulfoxide (DMSO), 20-40 $\mu \mathrm{M}$ of mucoroidiol (1) or firmibasiol (2). The relative cell number was assessed using Alamar blue (cell number indicator) and half maximal (50\%) inhibitory concentration ( $\mathrm{IC}_{50}$ ) of $\mathbf{1}$ and $\mathbf{2}$ was determined as described previously [31].

\subsection{Measurement of Minimum Inhibitory Concentration (MIC)}

The Gram-positive bacteria methicillin-susceptible Staphylococcus aureus (MSSA; strain ATCC29213), methicillin-resistant S. aureus (MRSA; ATCC43300) and the Gram-negative bacterium Escherichia coli (ATCC25922) were used in this study. The bacteria suspended in Mueller-Hinton broth $\left(5 \times 10^{5} \mathrm{CFU} / \mathrm{mL}\right.$; $0.1 \mathrm{~mL} /$ well) were incubated for $24 \mathrm{~h}$ at $37^{\circ} \mathrm{C}$ in 96-well plates (Corning, NY, USA) in the presence of vehicle, various concentrations of serially diluted test compounds, or known antibiotics; MIC was defined as the lowest concentration of the additives that inhibited visible bacterial growth.

\subsection{Osteoclast Differentiation Experiments}

RAW264 cells were grown in $\alpha$-MEM containing $10 \%$ fetal bovine serum and passaged every 3 days. To differentiate into osteoclast, RAW264 cells were seeded at $4 \times 10^{3}$ cells/well in 96-well plates and cultured in the presence of RANKL (50 ng/mL) and each compound for 4 days. The cells were sequentially fixed with $10 \%$ formalin for $10 \mathrm{~min}$ and ethanol for $1 \mathrm{~min}$, and then dried. To measure the activity of tartrate-resistant acid phosphatase (TRAP), which is a marker enzyme of osteoclastogenesis, fixed cells were incubated in $100 \mu \mathrm{L}$ of citrate buffer ( $50 \mathrm{mM}, \mathrm{pH} 4.6)$ containing $10 \mathrm{mM}$ tartrate and $5 \mathrm{mM}$-nitrophenylphosphate for 30-60 min and the reaction mixtures were transferred into another well containing $100 \mu \mathrm{L}$ of $0.1 \mathrm{M} \mathrm{NaOH}$ solution. The absorbances at $405 \mathrm{~nm}$ were measured as TRAP activity.

Supplementary Materials: The NMR spectra of new compounds $\mathbf{1}$ and $\mathbf{2}$ are available online at http://www.mdpi. com/1420-3049/25/12/2895/s1.

Author Contributions: Conceptualization, H.K.; formal analysis, H.S., Y.K., H.I., K.T., A.S., Y.O., and H.K.; funding acquisition, Y.K. and H.K.; investigation, H.S., Y.K., H.I., K.T., H.E., and H.K.; project administration, H.K.; resources, H.S. and H.K.; Supervision, H.K.; writing-original draft preparation, Y.K. and H.K.; writing-review and editing, Y.K., A.S., Y.O., and H.K. All authors have read and agreed to the published version of the manuscript.

Funding: This work was funded in part by the Grants-in-Aid for Scientific Research (no. 16H03279 and 19H02837) from the Ministry of Education, Culture, Sports, Science and Technology (MEXT), Japan; the Platform Project for 
Supporting in Drug Discovery and Life Science Research (Basis for Supporting Innovative Drug Discovery and Life Science Research (BINDS)) from AMED (no. P18am0101100); the Takeda Science Foundation; Suzuken Memorial Foundation; the Uehara Memorial Foundation; and Tokyo Biochemical Research Foundation.

Conflicts of Interest: The authors declare no conflict of interest.

\section{References}

1. Newman, D.J.; Cragg, G.M. Natural Products as Sources of New Drugs over the Nearly Four Decades from 01/1981 to 09/2019. J. Nat. Prod. 2020, 83, 770-803. [CrossRef] [PubMed]

2. Li, J.W.-H.; Vederas, J.C. Drug Discovery and Natural Products: End of an Era or an Endless Frontier? Science 2009, 325, 161-165. [CrossRef] [PubMed]

3. Wolfender, J.-L.; Queiroz, E.F. New Approaches for Studying the Chemical Diversity of Natural Resources and the Bioactivity of their Constituents. CHIMIA 2012, 66, 324-329. [CrossRef] [PubMed]

4. Eichinger, L.; Pachebat, J.; Glockner, G.; Rajandream, M.-A.; Sucgang, R.; Berriman, M.; Song, J.; Olsen, R.; Szafranski, K.; Xu, Q.; et al. The genome of the social amoeba Dictyostelium discoideum. Nature 2005, 435, 43-57. [CrossRef] [PubMed]

5. Adl, S.; Simpson, A.G.B.; Lane, C.E.; Lukeš, J.; Bass, D.; Bowser, S.S.; Brown, M.W.; Burki, F.; Dunthorn, M.; Hampl, V.; et al. The Revised Classification of Eukaryotes. J. Eukaryot. Microbiol. 2012, 59, 429-493. [CrossRef] [PubMed]

6. Firtel, R.A.; Meili, R. Dictyostelium: A model for regulated cell movement during morphogenesis. Curr. Opin. Genet. Dev. 2000, 10, 421-427. [CrossRef]

7. Calvo-Garrido, J.; Carilla-Latorre, S.; Kubohara, Y.; Santos-Rodrigo, N.; Mesquita, A.; Soldati, T.; Golstein, P.; Escalante, R. Autophagy in Dictyostelium: Genes and pathways, cell death and infection. Autophagy 2010, 6, 686-701. [CrossRef]

8. Nichols, J.M.E.; Veltman, D.; Kay, R.R. Chemotaxis of a model organism: Progress with Dictyostelium. Curr. Opin. Cell Boil. 2015, 36, 7-12. [CrossRef]

9. Stuelten, C.; Parent, C.A.; Montell, D.J. Cell motility in cancer invasion and metastasis: Insights from simple model organisms. Nat. Rev. Cancer 2018, 18, 296-312. [CrossRef]

10. Annesley, S.J.; Fisher, P.R. Dictyostelium discoideum-a model for many reasons. Mol. Cell. Biochem. 2009, 329, 73-91. [CrossRef]

11. Kubohara, Y.; Kikuchi, H. Dictyostelium: An Important Source of Structural and Functional Diversity in Drug Discovery. Cells 2018, 8, 6. [CrossRef]

12. Takaya, Y.; Kikuchi, H.; Terui, Y.; Komiya, J.; Furukawa, K.-I.; Seya, K.; Motomura, S.; Ito, A.; Oshima, Y. Novel Acyl $\alpha$-Pyronoids, Dictyopyrone A, B, and C, from Dictyostelium Cellular Slime Molds. J. Org. Chem. 2000, 65, 985-989. [CrossRef]

13. Kikuchi, H.; Nakamura, K.; Kubohara, Y.; Gokan, N.; Hosaka, K.; Maeda, Y.; Oshima, Y. Dihydrodictyopyrone A and C: New Members of Dictyopyrone Family Isolated from Dictyostelium Cellular Slime Molds. Tetrahedron Lett. 2007, 48, 5905-5909. [CrossRef]

14. Nguyen, V.H.; Kikuchi, H.; Sasaki, H.; Iizumi, K.; Kubohara, Y.; Oshima, Y. Production of novel bispyrone metabolites in the cellular slime mold Dictyostelium giganteum induced by zinc(II) ion. Tetrahedron 2017, 73, 583-588. [CrossRef]

15. Kikuchi, H.; Saito, Y.; Komiya, J.; Takaya, Y.; Honma, S.; Nakahata, N.; Ito, A.; Oshima, Y. Furanodictine A and B: Amino Sugar Analogues Produced by Cellular Slime Molds Dictyostelium discoideum Showing Neuronal Differentiation Activity. J. Org. Chem. 2001, 66, 6982-6987. [CrossRef] [PubMed]

16. Kikuchi, H.; Saito, Y.; Sekiya, J.; Okano, Y.; Saito, M.; Nakahata, N.; Kubohara, Y.; Oshima, Y. Isolation and Synthesis of a New Aromatic Compound, Brefelamide, from Dictyostelium Cellular Slime Molds and Its Inhibitory Effect on the Proliferation of Astrocytoma Cells. J. Org. Chem. 2005, 70, 8854-8858. [CrossRef]

17. Kikuchi, H.; Ishiko, S.; Nakamura, K.; Kubohara, Y.; Oshima, Y. Novel prenylated and geranylated aromatic compounds isolated from Polysphondylium cellular slime molds. Tetrahedron 2010, 66, 6000-6007. [CrossRef] 
18. Kikuchi, H.; Matsuo, Y.; Katou, Y.; Kubohara, Y.; Oshima, Y. Isolation, synthesis, and biological activity of biphenyl and $m$-terphenyl-type compounds from Dictyostelium cellular slime molds. Tetrahedron 2012, 68, 8884-8889. [CrossRef]

19. Kikuchi, H.; Ito, I.; Takahashi, K.; Ishigaki, H.; Iizumi, K.; Kubohara, Y.; Oshima, Y. Isolation, Synthesis, and Biological Activity of Chlorinated Alkylresorcinols from Dictyostelium Cellular Slime Molds. J. Nat. Prod. 2017, 80, 2716-2722. [CrossRef]

20. Zhang, J.; Yamada, O.; Kida, S.; Matsushita, Y.; Murase, S.; Hattori, T.; Kubohara, Y.; Kikuchi, H.; Oshima, Y. Identification of brefelamide as a novel inhibitor of osteopontin that suppresses invasion of A549 lung cancer cells. Oncol. Rep. 2016, 36, 2357-2364. [CrossRef]

21. Bai, G.; Matsuba, T.; Kikuchi, H.; Chagan-Yasutan, H.; Motoda, H.; Ozuru, R.; Yamada, O.; Oshima, Y.; Hattori, T. Inhibition of inflammatory-molecule synthesis in THP-1 cells stimulated with phorbol 12-myristate 13-acetate by brefelamide derivatives. Int. Immunopharmacol. 2019, 75, 105831. [CrossRef] [PubMed]

22. Zhang, J.; Yamada, O.; Kida, S.; Murase, S.; Hattori, T.; Oshima, Y.; Kikuchi, H. Downregulation of PD-L1 via amide analogues of brefelamide: Alternatives to antibody-based cancer immunotherapy. Exp. Ther. Med. 2020, 19, 3150-3158. [CrossRef] [PubMed]

23. Kubohara, Y.; Okamoto, K. Specific Induction by Zinc of Dictyostelium Stalk Cell Differentiation. Exp. Cell Res. 1994, 214, 367-372. [CrossRef] [PubMed]

24. Rabe, P.; Rinkel, J.; Nubbemeyer, B.; Köllner, T.G.; Chen, F.; Dickschat, J.S. Terpene Cyclases from Social Amoebae. Angew. Chem. Int. Ed. 2016, 55, 15420-15423. [CrossRef]

25. Chen, X.; Luck, K.; Rabe, P.; Dinh, C.Q.; Shaulsky, G.; Nelson, D.R.; Gershenzon, J.; Dickschat, J.S.; Köllner, T.G.; Chen, F. A terpene synthase-cytochrome P450 cluster in Dictyostelium discoideum produces a novel trisnorsesquiterpene. eLife 2019, 8. [CrossRef]

26. Raola, V.K.; Chakraborty, K. Two rare antioxidative prenylated terpenoids from loop-root Asiatic mangrove Rhizophora mucronata (Family Rhizophoraceae) and their activity against pro-inflammatory cyclooxygenases and lipoxidase. Nat. Prod. Res. 2017, 31, 418-427. [CrossRef]

27. Asagiri, M.; Takayanagi, H. The molecular understanding of osteoclast differentiation. Bone 2007, 40, 251-264. [CrossRef]

28. Boyle, W.J.; Simonet, W.S.; Lacey, D.L. Osteoclast differentiation and activation. Nature 2003, 423, 337-342. [CrossRef]

29. Chen, X.; Köllner, T.G.; Jia, Q.; Norris, A.; Santhanam, B.; Rabe, P.; Dickschat, J.S.; Shaulsky, G.; Gershenzon, J.; Chen, F. Terpene synthase genes in eukaryotes beyond plants and fungi: Occurrence in social amoebae. Proc. Natl. Acad. Sci. USA 2016, 113, 12132-12137. [CrossRef]

30. Rinkel, J.; Rabe, P.; Chen, X.; Köllner, T.G.; Chen, F.; Dickschat, J.S. Mechanisms of the Diterpene Cyclases $\beta$-Pinacene Synthase from Dictyostelium discoideum and Hydropyrene Synthase from Streptomyces clavuligerus. Chem. Eur. J. 2017, 23, 10501-10505. [CrossRef]

31. Kubohara, Y.; Kikuchi, H.; Matsuo, Y.; Oshima, Y.; Homma, Y. Mitochondria Are the Target Organelle of Differentiation-Inducing Factor-3, an Anti-Tumor Agent Isolated from Dictyostelium discoideum. PLoS ONE 2013, 8, e72118. [CrossRef]

(C) 2020 by the authors. Licensee MDPI, Basel, Switzerland. This article is an open access article distributed under the terms and conditions of the Creative Commons Attribution (CC BY) license (http://creativecommons.org/licenses/by/4.0/). 